\title{
Falsity and Fiction in the "Allegory of Poets"
}

\section{Marguerite Mills Chiarenza}

In clarifying the distinction Dante draws in the Convivio (II.1) between the "allegory of poets," or fictitious allegory, and the "allegory of theologians," or scriptural allegory, Charles Singleton remarks that "the radical difference lies in the nature of the literal sense in the one and the other. The 'allegory of poets' . . is a mode in which the first and literal sense is one devised ... in order to conceal, and in concealing to convey, a truth. Not so in the other mode. . . There the first sense is historical ... and not 'fiction'."1 Such a difference is indeed radical, for it is one thing to search for meaning in reality and another to attribute to one meaning another meaning.

Part of what the distinction of the two allegories implies is that, where God creates, a poet must invent. Since most critics follow Singleton in recognizing that somehow Dante's description of the allegory of theologians fits his poem better than that of the allegory of poets, they have found themselves involved in subtle discussions on whether Dante's invention is to be considered an invention and in attempts to better define in what sense it is, and in what sense it is not, fiction. ${ }^{2}$ While such discussions are, in my opinion, suggestive and useful, I also believe that they are more theoretical than historical and that we can simplify the problem, at least for the duration of the preliminary step I wish to take here, by remembering that, when Dante described the allegory of poets, he referred specifically to a fable in Ovid. We might then consider the probability that his description was primarily intended to fit classical pagan poetry; in particular the mythological tales so closely associated with that poetry. Once we compare scriptural allegory to mythological poetry, rather than to fiction in general, it becomes clear that the literal levels of the two are not merely different, but rather opposing. In fact, the letter of the one portrays revealed truth, that of the other pagan and superstitious lies. It also becomes clear that Dante, who was neither God nor a pagan, would no doubt consider his work distinct from, although related to, both types of allegory. 
While I am certain that many would disagree with my suggestion that the well known passage in the Convivio concerned so specifically, perhaps even exclusively, the characteristics of mythological poetry, ${ }^{3}$ think they would still concede that the myths portrayed by the poets represent, in the extreme falsity of their literal levels, an exasperated form of the poets' allegory. In fact, different from parables, for instance, in which the literal level, though not true, may be realistic and exemplary of reality, the myths are absurd tales which contradict reality as well as truth. When treating the myths, the early fathers attacked them precisely on the grounds that they were neither truthful nor realistic and, because of the myths, they began systematically to refer to poets as liars. This epithet, which was associated with poets throughout the Middle Ages, was aimed directly against the literal level of their works. In fact, the very fathers engaged in combatting the gods portrayed by the poets were willing to concede that truth could be hidden beneath the letter of the fables. They were even anxious to concede this, for such a hidden truth denied the validity of the fables themselves. A god who was but a symbol invented by a poet to portray a natural phenomenon was not a god at all. ${ }^{4}$

In Christian times, allegory was first used as an interpretation of mythology in order to destroy the poets' credibility, although not necessarily the poets themselves. Later, after the gods and their stories had ceased to exist as an ideological alternative to Christianity and had become exclusively representations of poetry, allegory was used in defense of the poets. But, the defenders and the attackers of myth had in common that, at least ideologically, they tolerated or accepted on the allegorical level what they rejected on the literal level. ${ }^{5}$ The double approach of the early fathers is understandable, for it served a practical purpose within their historical context. It was reasonable of them to reject the poets only so far as was necessary to achieve their goal of refuting the religion whose gods were portrayed by the poets. But the later centuries' defense of poetry based on a partial rejection is simply inconsistent. Henri de Lubac cites an indicative passage in which three possible approaches to mythological poetry are described: the myths can either be understood allegorically by the philosophers, believed foolishly by the pagans, or rejected truthfully by the Christians. Typically, the first - to understand allegorically - and the third - to reject truthfully - are not considered incompatible. ${ }^{6}$

While allegorization of the myths was an interpretive device 
inherited from antiquity, there was one form of it, the Christianization of myth, which was, of course, peculiarly medieval. In the late Middle Ages, the truth the allegorizers found behind the fable was not necessarily philosophical or scientific; it could just as well be specifically Christian, or even revealed, truth. Although the point of these interpretations was clearly to salvage the respectability of poets like Ovid and to encourage the reading of them, their authors could not have thought that the texts they interpreted in any way implied the interpretations they proposed. Obviously, they did not deem this necessary. They simply suggested a truthful and edifying reading of a false text. Only a friend of poetry could ignore the incompatibility of the letter and the allegory in such interpretations. In fact, the enemies of poetry did not accept that a lying literal level could reveal, by concealing, the truth it contradicted?

The irrelevance of the letter to the message was not a feature of the far more impressive medieval doctrines of the allegory of Scripture and the allegory of Nature. God revealed truth through reality, not through lies. Specifically, he drew Providence into the lines of history and harmony into those of nature, so that His invisible truth might be revealed through visible reality. His letter in no way contradicted His allegory and only concealed or hid it from those whose reading was faulty. While the principles of the allegory of Scripture and of reality reflect deeply the ideology of the Middle Ages, those of mythological allegory are ultimately a contradiction of it. As a matter of fact, the allegorization of myth was, in Christian times - as it had been in pagan times - more than anything else a way of justifying the absurdity of the poets' tales. In other words, allegory was needed as a formula to preserve the venerability of a literary tradition which the defenders of poetry were unwilling to reject, even on ideological or religious grounds. Returning to the concepts of the allegory of theologians and the allegory of poets, they do not seem to be two variations of the same cultural phenomenon at all: the first reflects the Middle Ages' faith that the visible signifies the invisible, the second is an apology for a poetic tradition which could not be ideologically justified on the literal level or, which is the same, in its own terms.

While the principles of allegory sacrificed the literal level of mythological poetry, in practice the myths appeared in medieval writings with a decorative function as often as they did with an allegorical intent. Toward the close of the Middle Ages, the practice began to overshadow the theory and, around the middle of the fourteenth century, we encounter a turning point in the 
treatment of classical myth in Boccaccio's Genealogie Deorum Gentilitum: a monumental, encyclopaedic type work which was intended to present its reader with all that was known of the ancient fables. Boccaccio's attempt to deal so inclusively and on such a large scale with the stories of the gods was unprecedented in the Middle Ages, but was rewarded with unqualified success in the Renaissance. In fact, not only were the Genealogie used intensively as a reference text in the centuries that followed, but they were also imitated in, and supplemented by, a series of other encyclopaedic works on mythology. ${ }^{8}$

With Boccaccio, disregard and ideological contempt for the face value or literal details of the myths is replaced by a focusing on the literal levels of the fables as aesthetic formalities. Allegorical meaning sinks into the background and, while Boccaccio does follow his descriptions of the variations on the stories of the gods with some - mostly traditional - allegories, the attention and space given to this aspect is minor compared to that devoted to the elaboration of the stories themselves. Boccaccio's large scale work on the formalities of the myths both dignified their literal level and prepared the ground for the highly formalized treatment they were to receive during the Renaissance.

However, the Genealogie does not just mark the formal beginning of a new attitude, but also reflects, in a variety of ways, the doctrines of an age which had not ended and the controversies which would continue beyond it. ${ }^{9}$ By accompanying his work with two final chapters of apology, Boccaccio reveals his need for an apology; not just for myth, but principally for poetry itself, as the propagator of myth. ${ }^{10}$ When, at one point, he breaks off in his apology to paraphrase the Creed and thereby testify that the study of the gods has not contaminated him with worship for them, ${ }^{11}$ he reflects the ideological threat that the literal level of pagan poetry still held for his age. Another indication of the prevailing positions in Boccaccio's time is to be found in the long series of specific attacks he anticipates, including: that poetry is useless; that composing stories is damnable; that poetry is obscure; that poets are liars; and that poets are the apes of philosophers. ${ }^{12}$ While a few of Boccaccio's answers to these expected accusations tend toward a defense of ornamentation as an end in itself, most of them lean heavily on the doctrine of allegory as the truth hidden beneath a lie, revealing that even Boccaccio had no more convincing argument than that of allegory with which to defend the beloved tales of the pagan poets.

Still - though perhaps in a more pragmatic than ideological way - Boccaccio's work did determine a new direction in the 
treatment of myth, whose literal level was somewhat redeemed by a greater emphasis placed on its formalities. The same cannot be said of Dante's treatment of mythology, which is much more accurately described as a solution of medieval tendencies than as an opening toward Humanistic or Renaissance ones. On the one hand, he rejected anything, literary or other, which denied reality or was untruthful and, unlike Boccaccio, he did not accept to any degree the notion of literature as an end in itself, or of a lie as justified by its beauty. On the other hand, he was committed to a unique and functional role for poetry and to the pagan tradition with which poetry had attained, in his view, its greatest heights. Thus, he was subjected directly to the conflict between tradition and ideology which had all along been an underlying feature of the standards of medieval mythological allegory.

In confronting this conflict, he neither chose the traditional road of relegating all falsity to the literal level of the myths he represented in his poem, nor did he seek to obscure their falsity by stressing their ornamental function. Rather, he attempted to relate the allegorical function directly to the literal level, or to make the letter demand a truthful reading, rather than to simply allow for a truthful but independent interpretation. In the Divine Comedy, Dante tampered with and manipulated the traditional myths, he contaminated them with Christian details, he placed them in positions in the poem where their association with a crucial aspect of his message could not be missed. All of these features of Dante's mythological imagery serve the purpose of fusing the truthfulness of the message with the story itself, or substituting an allegorical meaning confounded by the letter with an allegory implicit in it.

To clarify my description of Dante's use of mythology in the poem, I will offer just one example. The Paradiso begins with an invocation to Apollo, who is called upon to aid the poet in his attempt to speak of those things which exceed human comprehension. The god is asked to come to the mortal's aid and to act as he did on the occasion in which he stripped Marsyas of his flesh to punish the Satyr for challenging him to a musical contest. Dante ends the invocation by reminding Apollo that the ambition to reach beyond human limits should be cause for redundant joy in the god. The invocation hardly makes sense, unless its literal obscurity is resolved in terms of a direct contradiction of the pagan context of the traditional story of the musical contest between Marsyas and Apollo. The threat that the mortal's rivalry presented to the pagan god is irrelevant to the Christian God. The contest cannot be seen as between rivals. A Christian parallel, Dante seems to suggest, is for a mortal to seek to reach the true God, and this is a 
source of redundant joy to the God of Charity. If a Christian can obtain the goal of such striving, then his ultimate fulfilment can be seen as a kind of lifting of him from his earthly flesh. ${ }^{13}$ Dante's allusion to the pagan myth is comprehensible only in a Christian, and therefore truthful, context. Thus, the truthfulness traditionally relegated to the fable's allegorical level, lies within the arrangement of its literal elements.

Within medieval ideology, God's invisible truth could only be approached through visible reality, which God created to this end. For Dante the realism of his work was in its power to imitate reality, and to truly imitate reality meant to function as reality and, therefore, to reflect through a literal representation an intangible truth whose only source was the representation itself. Tradition had allowed, somewhat incongruously, that a poet's work might be simultaneously literally false and allegorically true. Much more coherently, Dante conceived of a representation which, though false to the letter of reality, was true to its spirit; and to be true to the spirit of reality meant to be implicitly meaningful. Thus, rather than saying that Dante wrote an allegory of theologians, we might simply say that he attempted to break away from a contradictory tradition related to poetic allegory; that, in fact, by writing into the lines of the letter an allegory comprehensible only through it, not independently from it, he rejected both the notion of an ideologically superfluous literal level and that of an independently true allegorical one.

Obviously, my rather schematic remarks do not constitute a full discussion of the matter. But, the points I wish to make are finally quite simple. The trend since Singleton has been, on the one hand, to investigate very thoroughly and historically the nature of the allegory of theologians but, on the other, to almost take for granted that the allegory of poets can be understood in the light of modern notions of fiction. I would like to suggest that it was not the ambiguity of fiction as such that was most directly responsible for Dante's innovations in allegory, but rather the ambivalence of his being a Christian poet in a pagan tradition. The allegory Dante produced for the Comedy need not be seen as a paradoxical invention of the truth, for it cannot be explained, I think more historically, as the result of his need to guarantee that the truth he could only read into pagan poetry was written into his. 
1 Charles Singleton, Dante Studies I: Commedia, Elements of Structure (Cambridge, Mass., 1954), p.14.

2 For a bibliography of discussions of the nature of Dante's allegory, see Robert Hollander, Allegory in Dante's Commedia (Princeton, 1961), pp.321-335.

3 Of two critics who have written recently on my subject, Maria Picchio Simonelli, "Vernacular Poetic Sources for Dante's Use of Allegory," Dante Studies, 43 (1975), 131-142, would certainly disagree with me, while Robert Hollander, "Dante Theologus-Poeta," Dante Studies, 44 (1976), 91-136, might well agree. I, at least, agree strongly with his view that we commit an anachronism when we assume that the defense of poetry, with its great pagan heritage, was a foregone conclusion for Dante. The weakness of the case for poetry in Dante's time is a central issue for our understanding of his conception of allegory, and one that Hollander is exceptional in pointing out.

4 For a survey of the early fathers' treatment of mythology, see Jean Seznec, The Survival of the Pagan Gods, trans. Barbara F. Sessions (New York, 1953), pp.1-121. See also Harold Hagendahl, Lat in Fathers and the Classics: A Study on the Apologists, Jerome and Other Christian Writers (Göteborg, 1958).

5 The ambiguity of late medieval justifications of pagan poetry as allegory is extensively documented by Henri de Lubac in Exégèse Médievale: Les Quatre Sens de l'Ecriture (Paris, 1964), II, 2, 125-262.

6 Henri de Lubac, p.185.

7 The enemies of poetry are, of course, the theologians. For a discussion of the cogency of their arguments, see Robert Hollander's article cited above. Hollander also offers extensive bibliographical references on the subject.

8 See, e.g., Vincenzo Cartari, Le imagini colla Sposizione degli Dei degli Antichi (Venice, 1556); Natale Conti, Mythologiae sive Explicationis Fabularum Libri X (Venice, 1551). For a discussion and description of such works, see Jean Seznec, pp. 219-323.

9 For a discussion of the aspects I am speaking of in the Genealogie, see Etienne Gilson, "Poesie et Vérité dans la Genealogie de Boccace," Studi sul Boccaccio, 2 (1964), 253-282.

10 These two famous chapters are translated by Charles G. Osgood in Boccaccio on Poctry (Princeton, 1956).

11 Osgood, pp.123-129.

12 Osgood, pp.32-87.

13 For a fuller discussion of the meaning of the Marsyas image, see my article, "Pagan Images in the Prologue of the Paradiso," in Proceedings, Pacific Northwest Council on Foreign Languages, 26, Part 1, pp.133-136. 